\title{
PVC/CPE ÉS PVC/PMMA BLENDEK MECHANIKAI TULAJDONSÁGAINAK ÖSSZEHASONLÍTÁSA
}

\author{
Román Krisztina - Zsoldos Gabriella
}

\begin{abstract}
Absztrakt: A tanulmány célja az egyes PVC blendek mechanikai tulajdonságainak meghatározása és eltérö keverékek tulajdonságainak összehasonlítása. A PVC-t gyakran elegyítik más polimerekkel a mechanikai tulajdonságainak javítása érdekében. A CPE és a PMMA jelentős módosításokat okoz a keverék szerkezetének morfológiájában. A szívóság javítása érdekében CPE-t Klórozott polietilén) és a szilárdsági tulajdonságok hatásának növelésére PMMA [poli(metil-metakrilát)] polimert alkalmaztunk. Bizonyítottan mind a kettö anyag tulajdonság javító hatással rendelkezik, és összeférhető a PVC-vel. A blendeken végzett mechanikai vizsgálatok, mint: szakítóvizsgálat, ütövizsgálat, hajlítóvizsgálat, keménységmérés bizonyítják a szerkezeti változásokat. Az eredmények alapján a PMMA-t tartalmazó keverék ütővizsgálata során az anyag rigedségét, a szakítóvizsgálatból a cellák morfológiájára következtethetünk.
\end{abstract}

\begin{abstract}
In this study the mechanical properties of some PVC blends can be determined. Mostly miscibility is the PVC with other polymer to improve their mechanical properties. CPE and PMMA are significantly changes the mixing structure morphology. CPE (chlorinates polyethylene) is commonly used to modify the material toughness. PMMA [poly (methy-methacrylate) is has a significant effect on the impact behaviour of the PVC. Proved the CPE and PMMA have material properties correcting effect. In this paper we compare the mechanical properties of blends, such as: tensile-, impact-, bending- and hardness test. The all test demonstrated the structure changes. Based on the results, the impact test of the PVC blend with PMMA polymer gives information to the rigid structure, the cells morphology could be determined by the tensile test.
\end{abstract}

Kulcsszavak: PVC/CPE blend, PVC/PMMA blend, habosítás, mechanikai tulajdonságok

Keywords: PVC/CPE blend, PVC/PMMA blend, foaming, mechanical properties

\section{Bevezetés}

Manapság az egyik leggyakrabban alkalmazott polimer alapanyag a PVC. A PVC kiváló ár-érték, súly (cellás szerkezet miatt) arányának köszönhetően szinte minden felhasználási területen megtalálható (Notario et al., 2015). A PVC egy „vitatottan” sokoldalú anyag, amelynek az egyik legnagyobb és legjelentősebb felhasználója az építőipar. Így a legtöbb polimerhabot az említett iparágban alkalmazzák, a jó termikus és mechanikai tulajdonságuk miatt. A tulajdonságok és az ár/érték javítása, gazdaságosság szempontjából szokás termodinamikailag összeférhető polimereket elegyíteni. Ennek vizsgálata a termék leendő felhasználási területét fogja meghatározni (Kollár et al., 2013).

A poli(vinil-klorid)-ot gyakran elegyítik más polimerekkel az ütőszilárdság, szakítószilárdság és lágyítás céljából. A PMMA-t így a kiváló optikai és mechanikai tulajdonságai miatt elegyítjük a PVC-vel. Ez a típusú polimer megoldást jelenthet a feldolgozási paraméterek javítására és a lágyításra, mivel a PVC szerkezetében nem okoz migrációs problémákat. Emellett döntő hatással lesz az alap mátrix ömledék és mechanikai tulajdonságaira is (Hernández et al., 2000).

A polimerek kombinációja révén új és javított tulajdonsákokkat alakíthatuk ki az alappolimer mátrixban, így akár megnövekedett hömérsékleti tartományban is 
kémiai ellenállást és erősebb szerkezetet hozhatunk létre. A klórozott polietilént (CPE) általnosan alkalmazuk a PVC-hez ütésállóságjavító adalékként. A CPE pozitív hatással van a keverék tulajdonságaira. Nem illékony, így nem migrál ki a szerkezetből, hanem elegyedik a PVC-vel, ebből kifolyólag lényegesen megnövelhető a termék élettartalma. A CPE csökkenti a törékenységet, növeli az ütésállóságot és a tüzálloságot (Ivanova et al., 2009).

A keverékek vizsgálatával és alkalmazásával a habosított PVC szerkezetek fejlesztésével, a termékek biztonságosabbá és több területen is alkalmazhatóbbá válnának. A blendben a CPE gátolni fogja a repedések terjedését, ütésállóság javítását ezért a rideg fázisban lévő PVC szerkezetét és alkalmazását előnyösebbé teszi. A drágább ütésálló alapanyagok alkalmazása nélkül is olcsóbb és jobb minőségü termék állítható elö. Az elegyítés további előnye még, hogy a feldolgozás szempontjából egy homogén polimer keverék keletkezik, azaz technológiai összeférhetőségről beszélhetünk (Kollár, 2012).

\section{Anyag és módszer}

A natúr PVC hab keveréke a feldolgozáshoz szükséges adalékanyagok mellett, töltőanyagot és habosító anyagot tartalmaz (Titow, 1984). A PVC/CPE keverék klórozott polietilén tartalma: $36 \%$ klorid tartalmú. A keverékhez alkalmazott PVC 58-as K értékü. A PVC/PMMA blendhez a keverékbe $2 \mathrm{~mm}$ nagyságú PMMA granulátumot adagoltunk. Mind a két blend esetében az alkalmazott tömegarányos adagolás: 100/20. Az l. táblázat tartalmazza az elkészült keverékeken mért sürüség értékeket:

\section{1. táblázat: Sürüségmérés eredményei}

\begin{tabular}{lc} 
Minta & Sürüség $\left[\mathrm{g} / \mathrm{cm}^{3}\right]$ \\
\hline Natúr PVC hab & 0,7027 \\
PVC/CPE & 0,9261 \\
PVC/PMMA & 0,8279
\end{tabular}

Forrás: A szerzỏ saját szerkesztése

A habosított minták sürüsége fontos szerepet játszik a cellák fizikai tulajdonságaiban.

\subsection{Próbatest készítés}

A PVC port és annak adalékanyagait száraz keverőben elegyítettük $110^{\circ} \mathrm{C}$-ig, megfelelő homogenizálás érdekében.

$4 \mathrm{~mm}$ vastagságú szerszámmal ellátott kétcsigás extrúderrel gyártottuk a minta lapjait, amelyből ZWICK típusú pneumatikus próbatest stancoló berendezéssel a vizsgálatokhoz elöírt szabvány szerinti próbatesteket vágtunk ki.

\section{Módszer}

A habkeverékek mechanikai tulajdonságait nagymértékben az anyag belső cellás szerkezet fogja befolyásolni, úgymint cellaméret, cellaalak, cellafal vastagság és az 
anyag sürüség. Habminták esetén szokás, nyomási-, ütő-, húzó-és nyíróvizsgálatokat végezni, a minél szélesebb körü anyagtulajdonságok megismerése érdekében (Wypych, 2015).

A szakító-, és hajlítóvizsgálatot egy INSTRON 5566 típusú univerzális anyagvizsgáló berendezéssel határoztuk meg, ahol a szakítószilárdsági; hajlítószilárdsági és hajlítómodulus értékeit kaptuk meg. Az ütővizsgálatokat CEAST 6545 berendezésen, a keménységvizsgálatot pedig Zwick/Roell Shore D mérőeszközzel vizsgáltuk.

A mérések során ASTM D638-10 és ISO178:2010 standard módszert alkalmaztam a mủanyagok tulajdonságainak meghatározására (ASTM, 2017; ISO, 2017.

A mérések nagy részében kereszt $(\mathrm{K})$ és hosszirányú $(\mathrm{H})$ méréseket is végeztünk, azaz az extrúdálás irányára merőlegesen és azzal egyező irányban is vizsgáltuk a tulajdonságokat. A két irányítottság vizsgálatának köszönhetően pontos képet kapunk az anyag tulajdonságairól, eltérő terheltségi hatások és különböző anyagösszetételek esetén.

\subsection{Keménységmérés}

A keménységmérés során egy keményebb behatoló testel szembeni ellenállás értékét mérjük. A keménységi értékeket ShoreD szúrószerszámú berendezéssel végeztük. A polimer-polimer rendszernek köszönhetően a blendek esetében keményebb habszerkezet alakult ki.

\section{2. táblázat: Shore $D$ keménységmérési eredmények}

\begin{tabular}{lc} 
Minta & \multicolumn{1}{c}{ Átlag } \\
\hline Natúr PVC hab & 39,60 \\
PVC/CPE & 55,05 \\
PVC/PMMA & 56,21
\end{tabular}

Forrás: A szerzö saját szerkesztése

A 2. táblázatban szereplő átlag értékeket minden keverék esetében 20 mérési eredmény átlagából határoztam meg.

Látható, hogy az alap hab keménységi értéke jóval alacsonyabb a többihez képest. Valószinüleg a polimer-polimer rendszerek között a kölcsönhatás erösebb és a blendek vastagabb cellafallal rendelkeznek. 


\subsection{Szakítóvizsgálat}

1. ábra: Hosszirányú szakítóvizsgálat eredményei

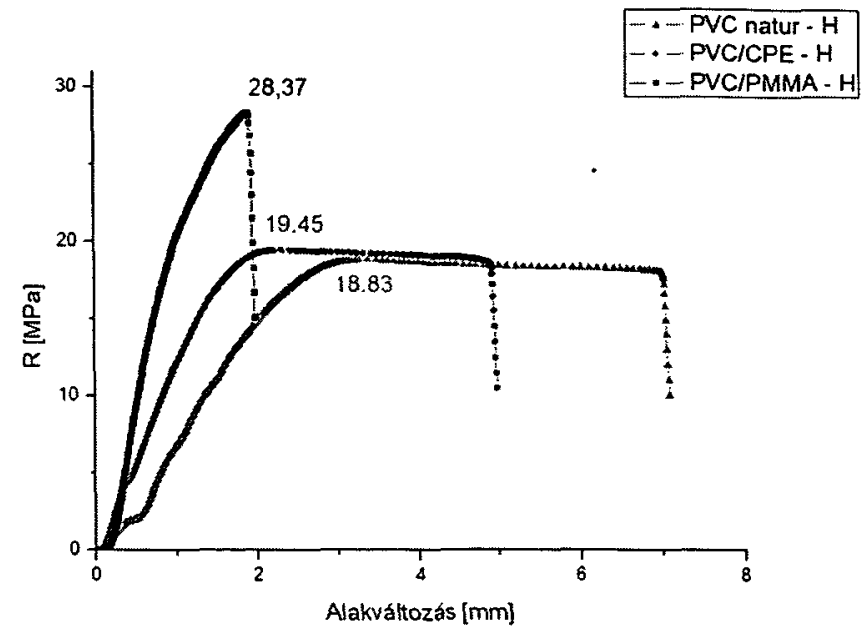

Forrás: A szerző saját szerkesztése

Szakítóvizsgálat során a keverékek egytengelyü húzó-igénybevétellel szembeni ellenállását mérjük. A vizsgálatokat $20^{\circ} \mathrm{C}$-os hőmérsékleten, $50 \%$ páratartalom és $200 \mathrm{~mm} / \mathrm{min}$ alakváltozási sebesség mellett végeztük.

2. ábra: Kereszt irányú szakítóvizsgálat eredményei

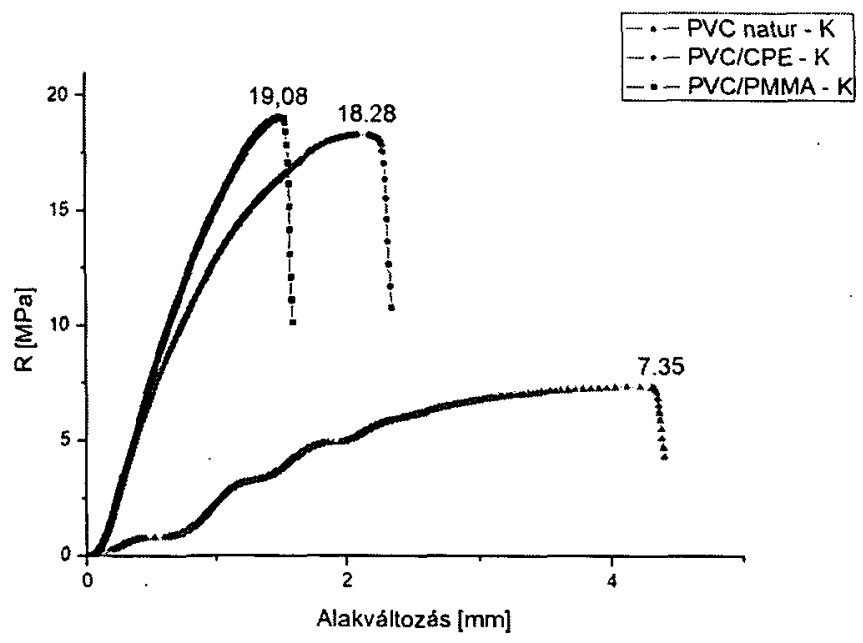

Forrás: A szerző saját szerkesztése

$\mathrm{Az}$ 1. és 2. ábrán látható, hogy hosszirányú húzóvizsgálat során a legjobb nyúlással a natúr keverék rendelkezik, míg a PMMA keverék a legnagyobb 
húzószilárdsági értékkel. A PMMA rideg viselkedését az 1 . ábra tükrözi, a többi keverékhez képest az anyag nyúlása elenyésző kereszt és hosszirányban is.

A szakítóvizsgálat eredményeiből meghatározhatjuk a cellás szerkezet morfológiáját. Látható, hogy a PMMA blend keresztirányú vizsgálatakor alacsonyabb eredmények születtek, mint hosszirány esetén, ebből az a következtetés vonható le, hogy az anyag szerkezetében lévő cellák anizotróp tulajdonságúak, erősen irányítottak.

A 3. táblázat összefoglalja az 1. és 2. ábrákban szereplö görbék legnagyobb szakítószilárdsági értékeit.

3. táblázat: Szakítóvizsgálat mérési eredményei

\begin{tabular}{lc} 
Minta & Szakítószilárdság [MPa] \\
\hline PVC natúr - H & 18,83 \\
PVC natúr - K & 7,35 \\
\hline PVC/CPE - H & 19,45 \\
PVC/CPE - K & 18,28 \\
\hline PVC/PMMA - H & 28,37 \\
PVC/PMMA - K & 19,08
\end{tabular}

Forrás: A szerző saját szerkesztése

\subsection{Hárompontos hajlító vizsgálat}

A hárompontos hajlító vizsgálat során a keverékek szilárdsági- és modulus értékeit határoztuk meg. A vizsgálat során szintén a PMMA és CPE erősítő hatását tapasztaltuk. A 4. és 5. táblázatban a CPE kereszt és hosszirányú szilárdsági értékei kimagaslóak, a natúr hab keverék értékeinek közel 3-szorosát érik el.

4. táblázat: Hajlító vizsgálat mérési eredményei

Minta Hajlítószilárdság [MPa]

\begin{tabular}{lr}
\hline PVC natúr - H & 19,22 \\
PVC natúr - K & 7,26 \\
\hline PVC/CPE - H & 31,33 \\
PVC/CPE - K & 28,61 \\
\hline PVC/PMMA - H & 34,00 \\
PVC/PMMA - K & 24,83
\end{tabular}

Forrás: A szerző saját szerkesztése

5. táblázat: Hajlító vizsgálat modulus értékei Minta Modulus

PVC natúr - H 762,00

PVC natúr $-\mathrm{K} \quad 234,76$

$\mathrm{PVC} / \mathrm{CPE}-\mathrm{H} \quad 1070,68$

PVC/CPE - K $\quad 949,65$

PVC/PMMA - H $\quad 1152,83$

PVC/PMMA - K 973,41

Forrás: A szerző saját szerkesztése 


\subsection{4. Ütővizsgálat}

Ütővizsgálat során a keverékek rideg és szívós tulajdonságait határoztuk meg. Az eddigi vizsgálatok alapján a PMMA magas szilárdsági értékekkel rendelkezett, míg dinamikus hírtelen bekövetkező ütés hatására az rideg törést eredményez.

\begin{tabular}{lc}
$\begin{array}{l}\text { 6. táblázat: Ütővizsgálat mérési eredményei } \\
\text { Minta }\end{array}$ & Ütőszilárdság $\left[\mathrm{kJ} / \mathrm{m}^{2}\right]$ \\
\hline PVC natúr - H & 2,19 \\
PVC natúr - K & 1,41 \\
\hline PVC/CPE - H & 2,61 \\
PVC/CPE - K & 3,47 \\
\hline PVC/PMMA - H & 2,32 \\
PVC/PMMA - K & 1,45
\end{tabular}

Forrás: A szerző saját szerkesztése

\section{Eredmények}

A vizsgálatok alapján polimer-polimer rendszerek/blendek alkalmazásával a habszerkezetek mechanikai tulajdonságai nagymértékben növelhetőek. Mivel egy habszerkezet a sürüségtöl, az anyagok kölcsönhatásaitól, feldolgozástól és a cellák morfológiájától függ, így ezekkel a mérésekkel az anyagok mechanikai tulajdonságait meghatározhatók. A vizsgálatok mindegyikében a PVC/CPE rendszer mutatott magas szilárdsági értékeket. Érdekes a CPE ütővizsgálat eredménye, mivel nem csak hosszanti irányban, de keresztirányban magasabb szilárdsági értékeket eredményezett. Így a PVC hab CPE erösítéssel többirányú terheléseknek is biztonságosan ellenáll. A PMMA erősítő hatását egyes vizsgáltok bizonyították, de ütővizsgálat során, dinamikus erőhatással szembeni ellenállása gyenge. A natúr kemény PVC habhoz képest jelentős mechanikai változásokat tapasztaltunk.

\section{5. Összegzés}

$\mathrm{Az}$ eredményekből következtethető, hogy a keverékek szerkezetében lévő cellák anizotrop tulajdonságúak. A CPE és PMMA habkeverékek tulajdonságaik alapján, olyan területen is alkalmazhatók, ahol a termékek nagyobb igénybevételeknek vannak kitéve. Az elkészített blendekkel drágább müszaki müanyagokból készült termékek is kiválthatók, amely gazdaságosság szempontjából például egy aljzat szigetelésére alkalmas termék előnyére irható.

A mechanikai tulajdonságok vizsgálata mellett további belső szerkezeti, termomechanikai tulajdonságok vizsgálata is szükséges lenne a különböző habok termikus viselkedés feltérképezése érdekében.

\section{Irodalomjegyzék}

ASTM International: Standard Test Method for Tensile Properties of Plastics. <https://www.astm.org/DATABASE.CART/HISTORICAL/D638-10.htm> (2017.10.20) 
Hernández, R., Pena, J. J., Irusta, L., Santamaría, A. (2000): The effect of a misciblie and an immiscible polymeric modifier on the mechanical and rheological propertied of PVC. European Polymer Journal, 36 (5): 1011-1025.

ISO 178:2010 Plastics - Determination of flexural properties. International Organization for Standardization. <https:/www.iso.org/standard/45091.html> (2017.10.20)

Ivanova, T., Elksnite, I., Zicns, J., Merijs, R., Kalnins M. (2009): Heterogeneous polyvinylchloride blends with chlorinated polyethylene:rheological, diffusion, and gas sorpation characteristics. Proceedeings of Estonian Acdemyof Sciences, 58 (1): 29-34.

Kollár M. (2012): Polimer keverékek készítésének elmélete. Anyagmérnöki Tudományok, 37 (1): 211-218.

Kollár M., Zsoldos G., Kállai I. (2013): Heterogén polimerrendszerek elméleti jellemzése és összeférhetőségének vizsgálata termoanalitikai módszerekkel, Müanyagipari szemle, Fiatalok fóruma, 10 (1): 1-18.

Notario, B.,Pinto, J., Rodríguez-Pérez, M. A. (2015): Towards a new generation of polymeric foams: PMMA nanocellular foams with enhances physical properties. Polymer Journal, (63): 116-126.

Titow, W. V (1984): PVC Technology. Elsevier Applied Science Publishers Ltd., England.

Wypych, G. (2015): PVC Degradation \& Stabilization. ChemtTech Publishing, Toronto. 